\section{Cureus}

Received 05/11/2017

Review began 05/15/2017

Review ended 05/22/2017

Published 05/29/2017

\section{(c) Copyright 2017}

Ali et al. This is an open access article distributed under the terms of the Creative Commons Attribution License CC-BY 3.0., which permits unrestricted use, distribution, and reproduction in any medium, provided the original author and source are credited.

\title{
A Review on the Role of Vitamin D in Asthma
}

\author{
Niloufer S. Ali ${ }^{1}$, Kashmira Nanji ${ }^{2}$ \\ 1. Family Medicine, The Aga Khan University 2. Epidemiology and Public Health, The Aga Khan \\ University, Karachi, PAK
}

$\square$ Corresponding author: Kashmira Nanji, kashmira.nanji@gmail.com

Disclosures can be found in Additional Information at the end of the article

\section{Abstract}

Asthma, a major public health issue, is one of the most common diseases affecting millions of population globally. It is a chronic respiratory disease characterized by increased airway inflammation and hyper-responsiveness. Vitamin D is of particular interest in asthma due to its immunomodulatory effects. Serum 25-hydroxyvitamin D is found to be associated with a wide range of pulmonary diseases, including viral and bacterial respiratory infections, asthma, and cancer. Several researches have reported positive associations between vitamin D and asthma. On the other hand, others have reported contrasting effects of vitamin D on asthma.

This review provides an examination of current epidemiologic and experimental evidence of a causal association between vitamin D status and asthma or asthma exacerbations, including its probable protective mechanism. Most of the evidence regarding vitamin D and asthma is reported by observational studies. Therefore, results from the experimental trials of vitamin D supplementation are important as they can provide evidence for future recommendations about the significance of vitamin D for asthma. Moreover, the trials can be effective in assessing the correct dosage and safety of vitamin D supplementation when given in diverse age groups such as children, teenagers, and adults for prevention and treatment of asthma.

Categories: Family/General Practice, Preventive Medicine, Epidemiology/Public Health Keywords: vitamin d, asthma, asthma morbidity, vitamin d deficiency, vitamin d insufficiency, immunomodulation

\section{Introduction And Background}

Asthma is one of the most common chronic diseases and its prevalence has increased worldwide in the last few decades affecting approximately 300 million people. This poses an immense burden on healthcare resources [1].

Asthma is a prolonged inflammatory disorder which is related with hyper responsiveness of the airways and leads to symptoms such as wheezing, dyspnea, chest tightness, and cough mainly at night or early in the morning [2]. The factors particularly responsible for asthma are not very clear because of its different presentation in both adults and children [3]. Interleukins (IL)-4, IL-5, and IL-13 (T-helper cell type-2 cytokines) are regulated in the asthmatic airway and are related with increased eosinophilia [3], mast cell degranulation [4], and increased levels of immunoglobulin E (IgE) [3-4]. The complex interaction between cells and inflammatory mediators and impairment of immunogenic tolerance promotes airway injury. This process is known as airway "remodeling" [5]. This process of remodeling involves hypertrophy of smooth muscle, hyperplasia of epithelial goblet cell, and deposition of airway extracellular matrix 
proteins which may lead to increase airflow obstruction and finally causing the respiratory symptoms [6].

Several dietary hypotheses have been proposed in context with asthma [7-8] and among them vitamin D status is of particular interest. Studies suggest that there is a probable relationship between vitamin D status and asthma-related symptoms presumably via the immunemodulatory effects of vitamin $\mathrm{D}[5,8]$.

\section{Risk factors of asthma}

Numerous risk factors of asthma can be divided into host and environmental factors.

\section{Host Factors}

Genetic: Several genes can be related to the pathogenesis of asthma. Four major areas have been focused in this regard; production of IgE antibodies, airway hyper-responsiveness, and inflammatory mediators (cytokines, chemokines), growth factors and the ratio between Th1 and Th2 immune responses [5-8].

Obesity: Obesity has been associated with the development of asthma. However, the biologic causality has not been yet proven [7,9].

Gender: Prevalence rates of asthma are different among males and females [8-9]. Childhood asthma is found to be common in boys than girls and by adulthood, this is reversed [10]. Reasons for this gender differences are not clear. However, the lung size is smaller in males than in females at birth but larger in adulthood [8-9].

\section{Environmental Factors}

Allergens: The role of allergens in the development of asthma in children is still unclear. It relies on the allergen, the dose, the time of exposure and the age of the child, and genetics can also play a role [10].

Infections: Evidence suggests that respiratory infections in early childhood may have a protective role against the development of asthma and studies have shown that they may develop asthma in later life $[8,11]$.

Tobacco smoke: Studies reveal that exposure to tobacco both prenatally or after birth can increase the risk of developing asthma-like symptoms in early childhood [12].

Outdoor/Indoor pollutants: The role of pollutants in the development of asthma is less well defined. It has been observed that increased levels of outdoor or indoor pollutions can aggravate asthma symptoms [12-13].

Diet: Studies have shown that infants fed with commercial cow's milk formula etc. have a higher frequency of wheezing illnesses in early childhood as compared to breast milk feeding infants [11, 13].

\section{Pathophysiology}

Narrowing of airway causes asthma and its symptoms [2]. Following are the factors which contribute to the development of this physiologic change [9-10]. 
In response to multiple broncho-constrictor, mediators and neurotransmitters the airway smooth muscle gets contracted and this leads to narrowing of the airway; this can be retreated by bronchodilators [10].

\section{Diagnosis of asthma}

It involves a careful process of history taking, physical examination, and diagnostic testing. The family history of asthma and atopic disease can also assist in diagnosing asthma $[12,14]$.

\section{Physical Examination}

The common abnormal physical finding on the examination is wheezing on chest auscultation. In severe cases, a silent chest can be found because of limitation of airflow and ventilation [2]. However, the other symptoms include: difficulty in speaking, drowsiness, tachycardia, cyanosis and use of accessory muscles and intercostal recession [14]. Confirmation of asthma is based on two additional elements $[2,14]$.

Spirometry: It is the preferred method of diagnosis of airflow obstruction. Peak flow measurements alone should not be used to diagnose asthma due to wide variability in predicted peak expiratory reference values. It may be more useful in monitoring patient's symptoms and response to therapy [14].

Exclusion of alternative diagnosis: Common acute causes of wheezing in children must be omitted before diagnosing asthma in children [14].

\section{Management}

The management of asthma involves controlling the clinical symptoms and maintaining it for a long term.

\section{Pharmacologic Treatment}

It can be divided into two categories: controllers and relievers.

Controllers: They are basically a preventive measure to keep asthma under control and taken daily on long term basis. Sometimes to reach clinical control add-on therapy with another class of controller is preferred over increasing the dose of inhaled corticosteroids [15-16].

Relievers: They are fast acting beta2 agonists and are the most effective medication for quick relief of bronchospasm in adults and children [15-16].

\section{Review}

\section{Vitamin D}

Vitamin D is a fat-soluble nutrient which is a modulator of calcium absorption and bone health. It also plays an important role in immune regulation and in respiratory infections [10, 17]. Serum 25OHD is the top indicator of overall vitamin D status since it reflects the intake of vitamin D from dietary sources intake as well as sun exposure; it also accounts for the adaptation of vitamin D from adipose stores in the liver [17]. Though, there are no guidelines on optimum levels of serum 25OHD. However, vitamin D deficiency is defined as 25OHD level of less than $50 \mathrm{nmol} / \mathrm{L}$ (20 ng per millilitre) [18]. When $25 \mathrm{OH}$ D levels are between 50 and 75 $\mathrm{nmol} / \mathrm{L}$ (20-30 ng per millilitre) it is an indicator of vitamin D insufficiency [18]. Moreover, 25OHD levels of $75 \mathrm{nmol} / \mathrm{L}$ (30 ng per millilitre) to $100 \mathrm{nmol} / \mathrm{L}$ suggest normal vitamin D levels. 
Vitamin D intoxication is defined as, serum levels of 25(OH) D are greater than $150 \mathrm{ng} / \mathrm{ml}[18]$.

\section{Vitamin D epidemiology}

Vitamin D deficiency has a high incidence worldwide. It is estimated that almost half of the healthy people population are 25-hydroxy-vitamin D (25-OH D) deficient [19]. Insufficient sun exposure or pigmented skin and inadequate dietary intake are the main causes of these low levels of 25-OH D [19]. A study conducted in the US on 9,757 subjects found that approximately $9 \%$ of participants had vitamin D deficiency and $61 \%$ had vitamin D insufficiency [20]. The common factors of vitamin D deficiency are increasing age, being female, Mexican-American ethnicity, obesity, and reduced dairy intake [19-20].

\section{Vitamin D deficiency in South Asia}

Sunlight exposure helps vitamin D production and in South Asia, almost all the days are sunny [21-22]. However, still, there is a high prevalence of vitamin D deficiency in these countries due to other underlying factors such as lack of proper diet, inadequate calcium intake, social culture and customs that require the elderly, children and females to be confined in the house, limiting their exposure to sunlight [20-21]. It has been reported that the prevalence of this deficiency ranges from $69 \%$ to $82 \%$ in Indian population [23-24]. This is not limited to the Asians living in India and Pakistan [5, 9], but even the immigrants (UK, Denmark, and Norway) have this deficiency [23-24].

\section{Vitamin D and immune system}

Vitamin D plays a significant part in inborn and adaptive immunity; however, it is not completely understood [9, 25]. It is reported that over 900 genes are regulated by vitamin D [26]. This action of vitamin D has gained immense acceptance after the discovery of vitamin D receptor (VDR). Several studies have shown that vitamin D prevents the increase of CD41 Tcells [25-26] and decreases the creation of Th1 cytokines IL-17 [10, 25-27]. However, due to alterations in target cells timing and quantity of vitamin administration, studies have shown contrasting results. Evidence suggests that innate immunity is activated by the production of anti-microbial peptide LL-37 by macrophages [25-27]. The adaptive immune system increases the production of T-cells and modifies the functions of antigen-presenting cells (APCs), of dendritic cells. In addition, vitamin D has been revealed to improve and inhibit IL-4 production by naive T-cells [25-27].

\section{Vitamin D and asthma}

It has been suggested that modernization and westernization have led to vitamin D deficiency among world population. Since, the majority of the population spends time indoors away from sun exposure, leading to vitamin D deficiency [21, 27].

The role of vitamin D in asthma is not yet clear. Few cross-sectional surveys had suggested a probable link between asthma and vitamin D [27-28]. Studies have concluded that decreased level of serum 25(OH)D is correlated with an increased prevalence, hospitalization, and increased emergency visits along with declined lung function and increased airway hyperresponsiveness in asthmatic children [27, 29]. Clinical trials conducted in recent times have shown the protective influence of vitamin D supplementation among asthmatic patients [3032]. In addition, increased intake of vitamin D during pregnancy has an influence on asthma in children and adults [33-34].

Evidence from the researches concludes that asthma exacerbations and resistance to common therapies are some of the major challenges to reduce asthma-related morbidity and mortality 
[29-34]. Studies are suggestive in support of a role of vitamin D in both these aspects [29-34].

\section{Evidence from Observational Studies}

A cross-sectional survey on 75 Italian asthmatic children found that the prevalence of vitamin D-deficiency was 53.3\% [28]. In another survey from North America, 17\% of asthmatics had vitamin D deficiency and a positive correlation was observed between vitamin D levels and lung function [29]. A study conducted by Thuesen, et al. on 4,999 Danish adults reported contrasting results and concluded that 25(OH)D levels do not have any effect on the development of asthma and allergic symptoms [35]. A cohort study revealed that low serum 25(OH)D levels at the age of 6 years predicted asthma-associated symptoms (uncontrolled asthma and lung function) at 14 years of age [36].

The data from observational studies has shown a parallel relation between vitamin $\mathrm{D}$ and asthma outcomes [36-39]. Although, it is challenging to formulate a relationship between them due to certain limitations of these studies such as the presence of bias (selection bias), confounders (physical activity, sex, age, etc.) and small sample size. All of the abovementioned limitations might have caused a spurious relation between vitamin $\mathrm{D}$ and asthma.

Cohort studies suggest that lower maternal dietary intake of vitamin D can result in the development of asthma morbidity and wheeze in children [40-42]. However, a major limitation of these studies was that they assessed vitamin D intake using food frequency questionnaires rather than directly measuring serum concentrations.

A study conducted by Gale, et al. shared that children whose mothers had serum $25(\mathrm{OH}) \mathrm{D}$ concentrations above $75 \mathrm{nmol} / \mathrm{L}$ had five times more risk of developing asthma at 9 years [33]. Studies conducted in Finland and Japan on more than 750 mother-child pair have found that dietary vitamin $\mathrm{D}$ intake during pregnancy is inversely related to the incidence of wheeze among children [41-42]. Another study concludes that serum 25(OH)D during late pregnancy was not related with maternal vitamin D status and risk of childhood asthma [43]. A study conducted by Zosky, et al. found that maternal vitamin D deficiency was positively related with asthma at 6 years in males (OR: 3.03; 95\% CI: 1.02-9.02) [40].

Comparison between the results of the studies should be done with caution, as these studies had a number of limitations, for instance, short follow-up duration, significant rates of attrition, and lack of validated measures for measuring serum vitamin D.

A study done in New Zealand revealed that low blood 25(OH) D levels were not associated with asthma incidence [44].

The relation between higher 25(OH)D levels and reduction in the incidence of asthma is contradictory and studies depicting a direct role for vitamin $\mathrm{D}$ in the development of asthma are required.

\section{Vitamin $D$ and asthma pathogenesis}

A study conducted by Gupta, et al. was the pioneer research in concluding that serum vitamin D levels were found to be lowest among children with steroid resistant asthma (STRA) [45] with reduced lung function, increased corticosteroid use, and asthma exacerbations. The probable reason for this is because low vitamin D levels increase the airway smooth muscle (ASM) and reduce lung function in severe asthma [45].

Evidence from Observational Studies 


\section{Cureus}

Vitamin D is only used for primary prevention for asthma but it also has a role in asthma exacerbation. A cross-sectional study of 616 asthmatic children in Costa Rica between the ages of 6 and 14 years, reported that vitamin D deficiency/insufficiency was prevalent in $28 \%$ of the children and increased levels of vitamin $\mathrm{D}$ were related with reduction in asthma exacerbations and reduced visits to emergency department (OR: 0.05; 95\% CI: 0.004-0.71) [20]. A 4-year longitudinal study was conducted by Brehm, et al. to establish causal relations between serum vitamin D levels and asthma exacerbations in 1024 North American asthmatic children with mild to moderate asthma [25]. This study confirmed that less levels of vitamin D $(<30 \mathrm{ng} / \mathrm{mL})$ had increased risk of asthma exacerbations (OR: 1.5; 95\% CI: 1.1-1.9) [25]. In addition, the study also concluded that children with vitamin D insufficiency had higher chances of asthma exacerbation [25].

Another cross-sectional study conducted on 560 children ages between 6 and 14 years with asthma in Puerto Rico reported that children with vitamin D insufficiency were 2.6 times more at risk of developing asthma exacerbations (OR: 2.6; 95\% CI: 1.5-4.9) [37]. A recent study conducted on 70 adult asthmatic patients and 20 healthy controls by Shahin, et al. [46], concluded that serum vitamin D level was significantly decreased in asthmatic patients $(19.88 \pm$ $9.6 \mathrm{ng} / \mathrm{ml})$ as compared to the control group $(33.5 \pm 6.1 \mathrm{ng} / \mathrm{ml})$ [46] (Table 1).

\begin{tabular}{|c|c|c|c|c|c|}
\hline Author & Year & Study Design & $\begin{array}{l}\text { Study } \\
\text { Sample }\end{array}$ & $\begin{array}{l}\text { Outcome } \\
\text { Measures }\end{array}$ & Findings \\
\hline $\begin{array}{l}\text { Brehm } \\
\text { [20] }\end{array}$ & 2009 & $\begin{array}{l}616 \text { children diagnosed } \\
\text { with asthma in Costa Rica }\end{array}$ & $\begin{array}{l}\text { Mild to } \\
\text { persistent } \\
\text { asthma }\end{array}$ & $\begin{array}{l}\text { Asthma } \\
\text { exacerbations }\end{array}$ & $\begin{array}{l}\text { Increased levels of vitamin D was } \\
\text { related with decreased } \\
\text { hospitalizations, use of steroids } \\
\text { and airway hyperresponsiveness }\end{array}$ \\
\hline $\begin{array}{l}\text { Chinellato } \\
\text { [28] }\end{array}$ & 2011 & $\begin{array}{l}\text { Cross-sectional survey of } \\
75 \text { children }\end{array}$ & $\begin{array}{l}\text { Controlled } \\
\text { and } \\
\text { uncontrolled } \\
\text { asthma }\end{array}$ & $\begin{array}{l}\text { Spirometry, asthma } \\
\text { controls }\end{array}$ & $\begin{array}{l}\text { Vitamin D levels were positively } \\
\text { correlated with asthma control }\end{array}$ \\
\hline Gale [33] & 2008 & $\begin{array}{l}\text { Birth cohort study of } 596 \\
\text { mother-child pairs }\end{array}$ & $\begin{array}{l}\text { Intake of } \\
\text { vitamin D } \\
\text { during } \\
\text { pregnancy }\end{array}$ & Serum 25(OH)D & $\begin{array}{l}\text { Maternal vitamin D levels were } \\
\text { linked with higher risk of asthma }\end{array}$ \\
\hline $\begin{array}{l}\text { Hollams } \\
\text { [34] }\end{array}$ & 2011 & $\begin{array}{l}\text { Cohort of 2,834 pairs } \\
\text { (mothers \& child) }\end{array}$ & $\begin{array}{l}\text { Subjects } \\
\text { with and } \\
\text { without } \\
\text { asthma }\end{array}$ & $\begin{array}{l}\text { Physician } \\
\text { diagnosed asthma }\end{array}$ & $\begin{array}{l}\text { Vitamin D status at } 6 \text { years of age } \\
\text { was predictive of asthma } \\
\text { symptoms at } 14 \text { years }\end{array}$ \\
\hline $\begin{array}{l}\text { Thuesen } \\
\text { [35] }\end{array}$ & 2016 & $\begin{array}{l}\text { Longitudinal study of } 4,999 \\
\text { Danish population aged } 30 \\
\text { to } 60 \text { years; } 3,032 \text { had } \\
\text { completed follow-up at } 5 \\
\text { years }\end{array}$ & $\begin{array}{l}\text { Subjects } \\
\text { with and } \\
\text { without } \\
\text { asthma }\end{array}$ & $\begin{array}{l}\text { Physician } \\
\text { diagnosed asthma }\end{array}$ & $\begin{array}{l}\text { Serum vitamin D levels do not } \\
\text { have influence on asthma among } \\
\text { adults }\end{array}$ \\
\hline $\begin{array}{l}\text { Freishtat } \\
\text { [36] }\end{array}$ & 2010 & $\begin{array}{l}\text { Case-control study of } 106 \\
\text { African American subjects } \\
6 \text { to } 20 \text { years of age }\end{array}$ & $\begin{array}{l}\text { Subjects } \\
\text { with and } \\
\text { without } \\
\text { asthma }\end{array}$ & $\begin{array}{l}\text { Physician } \\
\text { diagnosed asthma }\end{array}$ & $\begin{array}{l}\text { Vitamin D deficiency was related to } \\
\text { asthma }\end{array}$ \\
\hline
\end{tabular}




\section{Cureus}

\begin{tabular}{|c|c|c|c|c|c|}
\hline $\begin{array}{l}\text { Brehm } \\
{[37]}\end{array}$ & 2012 & 560 Puerto Rican kids & $\begin{array}{l}\text { Subjects } \\
\text { with and } \\
\text { without } \\
\text { asthma }\end{array}$ & $\begin{array}{l}\text { Physician } \\
\text { diagnosed asthma }\end{array}$ & $\begin{array}{l}\text { Vitamin D insufficiency was related } \\
\text { to increased odds of asthma } \\
\text { exacerbation (OR: } 2.6 ; 95 \% \mathrm{Cl} \text { : } \\
1.5-4.9 \text { ) }\end{array}$ \\
\hline $\begin{array}{l}\text { Miyake } \\
\text { [39] }\end{array}$ & 2010 & $\begin{array}{l}\text { Birth cohort of } 1,002 \\
\text { Japanese mothers and } \\
\text { child }\end{array}$ & $\begin{array}{l}\text { Maternal } \\
\text { consumption } \\
\text { of vitamin D }\end{array}$ & $\begin{array}{l}\text { Food-frequency } \\
\text { questionnaire }\end{array}$ & $\begin{array}{l}\text { Increased intake of vitamin D was } \\
\text { accompanied with a lower risk of } \\
\text { wheeze }\end{array}$ \\
\hline $\begin{array}{l}\text { Zosky } \\
{[40]}\end{array}$ & 2014 & $\begin{array}{l}\text { Prospective birth cohort } \\
\text { study with children }\end{array}$ & & $\begin{array}{l}\text { Serum } 25(\mathrm{OH}) \mathrm{D} \text { on } \\
16-20 \text { weeks of } \\
\text { gestation }\end{array}$ & $\begin{array}{l}\text { Maternal vitamin D deficiency had } \\
\text { impact on asthma in males }\end{array}$ \\
\hline $\begin{array}{l}\text { Devereux } \\
\text { [29] }\end{array}$ & 2014 & $\begin{array}{l}\text { Case-control study of } 160 \\
\text { adults in the United } \\
\text { Kingdom }\end{array}$ & $\begin{array}{l}\text { Subjects } \\
\text { with and } \\
\text { without } \\
\text { asthma }\end{array}$ & $\begin{array}{l}\text { Physician } \\
\text { diagnosed asthma }\end{array}$ & $\begin{array}{l}\text { No association between vitamin D } \\
\text { level and asthma }\end{array}$ \\
\hline $\begin{array}{l}\text { Erkkola } \\
\text { [42] }\end{array}$ & 2009 & $\begin{array}{l}\text { Birth cohort in Finland with } \\
3,565 \text { (mother-children) } \\
\text { with } 1,669 \text { children }\end{array}$ & $\begin{array}{l}\text { Susceptibility } \\
\text { to Type I } \\
\text { diabetes }\end{array}$ & $\begin{array}{l}\text { Maternal food- } \\
\text { frequency } \\
\text { questionnaire }\end{array}$ & $\begin{array}{l}\text { Increased maternal vitamin D } \\
\text { intake lowers risk of asthma }\end{array}$ \\
\hline $\begin{array}{l}\text { Morales } \\
{[43]}\end{array}$ & 2012 & $\begin{array}{l}\text { Prospective cohort of } 1724 \\
\text { children in Spain }\end{array}$ & $\begin{array}{l}\text { Maternal } \\
\text { intake of } \\
\text { vitamin D }\end{array}$ & $\begin{array}{l}\text { Maternal plasma } \\
25(\mathrm{OH}) \mathrm{D}\end{array}$ & $\begin{array}{l}\text { Increased maternal intake of } \\
\text { vitamin D was associated with a } \\
\text { lower risk of lower respiratory } \\
\text { infections }\end{array}$ \\
\hline $\begin{array}{l}\text { Camargo } \\
{[44]}\end{array}$ & 2011 & $\begin{array}{l}\text { Cohort of } 922 \text { newborns in } \\
\text { New Zealand, children }\end{array}$ & & $\begin{array}{l}\text { Cord blood } \\
25(\mathrm{OH}) \mathrm{D}\end{array}$ & $\begin{array}{l}\text { Higher } 25(\mathrm{OH}) \mathrm{D} \text { resulted } \\
\text { in reduced risk of respiratory } \\
\text { infections and wheezing but had } \\
\text { no effect on incidence of asthma }\end{array}$ \\
\hline $\begin{array}{l}\text { Shahin } \\
\text { [46] }\end{array}$ & 2017 & $\begin{array}{l}\text { Two groups. First group } \\
\text { included } 70 \text { adult } \\
\text { asthmatic patients and } 20 \\
\text { healthy adult control group }\end{array}$ & $\begin{array}{l}\text { Subjects } \\
\text { with and } \\
\text { without } \\
\text { asthma }\end{array}$ & $\begin{array}{l}\text { Vitamin D status in } \\
\text { patients with } \\
\text { asthma and its } \\
\text { relation to disease } \\
\text { control and severity }\end{array}$ & $\begin{array}{l}\text { Vitamin } D \text { levels were significantly } \\
\text { decreased in asthmatic patients } \\
(19.88 \pm 9.6 \mathrm{ng} / \mathrm{ml}) \text { as compared } \\
\text { with the healthy control group } \\
(33.5 \pm 6.1 \mathrm{ng} / \mathrm{ml})\end{array}$ \\
\hline
\end{tabular}

\section{TABLE 1: Observational studies of vitamin D and asthma morbidity}

Evidence from Clinical Trials

Clinical trials have provided suggestions that vitamin $\mathrm{D}$ has a protective role against asthma exacerbations. A randomized, double-blind 6-month clinical trial conducted by Majak, et al. found that children receiving supplemental $500 \mathrm{IU} / \mathrm{d}$ vitamin D had lower risk of asthma exacerbations when triggered through acute respiratory infections [31]. Another randomized, double-blind, parallel arm clinical trial by Urashima, et al. on 217 school children found that there was a lower risk of asthma exacerbations after vitamin D3 supplementation [30]. Other trial on 100 asthmatic children revealed that monthly doses of 60,000 IU of vitamin D can significantly decrease the number of exacerbations $(p=0.011)$ and it also resulted in the reduction of steroids $(p=0.013)$ and emergency visits $(p=0.015)$ [32]. A study conducted in 2016 in which Japanese schoolchildren with asthma $(n=89)$ were randomly assigned to either 


\title{
Cureus
}

receive vitamin $\mathrm{D}(\mathrm{n}=54)$ or placebo $(\mathrm{n}=35)$. At 2 months, asthma control was significantly more improved in the vitamin $\mathrm{D}$ group as compared to the placebo group $(\mathrm{p}=0.015)$ [47].

Some trials on vitamin D did not show statistical significance and remained inconclusive. A recent trial by Jensen, et al. found that preschool-aged children with asthma received 100,000 IU vitamin D3 or placebo, followed by 400 IU vitamin D3 daily for 6 months revealed that there was no significant difference in the Serum 25OHD between the groups [48]. Another study conducted to determine whether vitamin D supplementation reduces cold symptom occurrence and severity among asthmatics found that despite achieving 25(OH)D levels of $41.9 \mathrm{ng} / \mathrm{ml}$, vitamin D supplementation had no effect on the rate of colds between groups [49]. A study conducted by Martineau, et al. found that intermittent bolus dose of vitamin D3 to a daily lowdose regimen was associated with increased risk and duration of upper respiratory infections [50] (Table 2).

\begin{tabular}{|c|c|c|}
\hline Author & Year & Study Design \\
\hline $\begin{array}{l}\text { Urashima } \\
\text { [30] }\end{array}$ & 2010 & RCT of 217 school children \\
\hline Majak [31] & 2011 & $\begin{array}{l}\text { Randomized, double-blind, } \\
\text { parallel arm clinical trial 6-month } \\
\text { experimental study of vitamin D3 } \\
\text { ( } 500 \mathrm{IU} / \mathrm{d} \text { ) as adjuvant therapy to } \\
\text { IC among } 48 \text { Polish children }\end{array}$ \\
\hline $\begin{array}{l}\text { Yadav } \\
\text { [32] }\end{array}$ & 2014 & $\begin{array}{l}\text { Randomized double blinded } \\
\text { placebo controlled trial on } 100 \\
\text { children } 1 \text { group received vitamin } \\
\text { D3, } 60,000 \mathrm{IU} / \text { month for } 6 \text { months } \\
\text { versus placebo }\end{array}$ \\
\hline
\end{tabular}

Tachimoto

[47] 2016

Treatment $(n=54)$ : vitamin D3 $800 \mathrm{IU} /$ day orally for 2 months. Control $(n=39)$ : daily oral placebo for 2 months

Active intervention $(n=11)$ : 100,000 IU vitamin D3 oral bolus at baseline, followed by $400 \mathrm{IU}$ Jensen [48]
2016 vitamin D3 IU orally daily. Control

Study
Sample
All school
children
with
subgroup
with
clinically
diagnosed
asthma

Newly diagnosed asthma

Asthmatic
children

Asthma exacerbations and number of emergency visits

Changes in asthma control Asthmatic children (6 to 15 years)

Asthmatic
preschool
children
(1 to 5

Asthmatic

\section{Findings}

Vitamin supplements reduced the risk of severe asthmatic symptoms Mean group change in total serum $25(\mathrm{OH}) \mathrm{D}$ from baseline to 3

levels defined by GINA. Changes in asthma control levels judged by the childhood ACT

$$
\text { vitamin D group }
$$

Group difference in serum 25OHD (7.2 nmol/L; 95\% Cl: (13.7-28.1) was not significant; $100 \%$ vs $54.5 \%$ (intervention versus control) placebo group ( $p=0.015)$. (CACT) scores were also significantly improved in
Children receiving vitamin $\mathrm{D}$ supplementation had lower incidence of asthma exacerbations as compared to other groups

Vitamin $D$ has a role in bronchial asthma

Asthma control was significantly improved in vitamin $D$ group versus Childhood asthma control test intervention ( $n=11)$ : oral placebo
(1 to 5

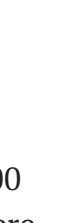




\section{Cureus}

\begin{tabular}{|c|c|c|c|c|c|}
\hline & & $\begin{array}{l}\text { at baseline, followed by } 400 \\
\text { vitamin D3 IU orally daily }\end{array}$ & years) & months & $\begin{array}{l}\text { had serum } 250 H D \geq 75 \\
\mathrm{nmol} / \mathrm{L}\end{array}$ \\
\hline $\begin{array}{l}\text { Denlinger } \\
\text { [49] }\end{array}$ & 2015 & $\begin{array}{l}\text { Cholecalciferol (100,000 IU load } \\
\text { plus } 4,000 \mathrm{IU} / \mathrm{d} \text { ) for } 28 \text { weeks or } \\
\text { placebo }\end{array}$ & $\begin{array}{l}\text { Adults } \\
\text { with } \\
\text { asthma }\end{array}$ & $\begin{array}{l}\text { Cold symptom } \\
\text { severity, which } \\
\text { was assessed } \\
\text { using daily scores } \\
\text { on the } 21 \text {-item } \\
\text { Wisconsin Upper } \\
\text { Respiratory } \\
\text { Symptom Survey }\end{array}$ & $\begin{array}{l}\text { Vitamin D supplementation } \\
\text { had no effect on the average } \\
\text { peak scores ( } 62.0 \text { [ } 95 \% \mathrm{Cl} \text { : } \\
55.1-68.9 \text {; placebo] and } 58.7 \\
\text { [95\% Cl: } 52.4-65.0 \text {; vitamin } \\
\text { D]; } p=0.39)\end{array}$ \\
\hline $\begin{array}{l}\text { Martineau } \\
\text { [50] }\end{array}$ & 2015 & $\begin{array}{l}\text { Six } 2 \text {-monthly oral doses of } 3 \text { mg } \\
\text { vitamin D3 }(n=125) \text { or placebo ( } n \\
=125) \text { over } 1 \text { year }\end{array}$ & $\begin{array}{l}\text { Adults } \\
\text { with } \\
\text { asthma }\end{array}$ & $\begin{array}{l}\text { Asthma } \\
\text { exacerbations and } \\
\text { URI }\end{array}$ & $\begin{array}{l}\text { No significant association to } \\
\text { first severe exacerbation (HR: } \\
\text { 1.02, 95\% Cl: } 0.69-1.53, p= \\
0.91 \text { ) or first URI (HR: } 0.87 \text {, } \\
95 \% \mathrm{Cl}: 0.64-1.16, p=0.34)\end{array}$ \\
\hline
\end{tabular}

\section{TABLE 2: Trials of vitamin D and asthma morbidity}

GINA: Global Initiative for Asthma; RCT: Randomized clinical trial.

These data certainly are suggestive of a relation of vitamin D in asthma and can be useful as an adjunct therapy to overcome steroid resistance in severe asthma. There are many studies on the influence of vitamin D on responses to infection, but there are none or limited studies to determine the causal role of vitamin D deficiency during acute asthma exacerbation.

\section{Future perspectives}

Most of the observational researches have demonstrated the benefit of vitamin D supplementation in asthmatic patients. Nevertheless, to address the limitation of temporality in the observational studies, clinical trials are required to establish the association between vitamin D and asthma.

Trials with larger sample sizes are needed to provide the evidence of causality for vitamin D and asthma. These trials will also be helpful in establishing the appropriate route, dose, and safety of vitamin D supplementation for prevention and treatment of asthma.

It is also imperative to realize the protective mechanism of vitamin $\mathrm{D}$ against asthma. The suppression of Th2 immune response explains the protective effect of vitamin D alongside asthma. Nonetheless, there is a need to identify evidence between vitamin $\mathrm{D}$ and atopic reactions.

There is no evidence to suggest that asthmatic patients should be screened for vitamin D deficiency or insufficiency. However, the high-risk group (obese patients and elderly of AfricanAmerican ethnicity who have limited sun exposure) must be screened for this deficiency.

Further researches are needed on the molecular level of vitamin D receptor to explain the role of dietary vitamin $\mathrm{D}$ in the prevention and management of asthma. 


\section{Conclusions}

Vitamin D can be effective as an adjunct therapy in the management of asthma. The higher levels of vitamin D, in fact, are needed to prevent various health problems. Regardless of the growing evidence about the association of vitamin $\mathrm{D}$ with asthma and asthma exacerbation, the results of the studies are not reliable. Several studies have supported the view that vitamin D deficiency is the cause of the global asthma epidemic. On the other hand, another set of studies has proposed that vitamin D supplements are responsible for the asthma epidemic.

However, larger trials with huge sample sizes are required to define the role of vitamin D in asthma and answer questions that whether vitamin D supplementation will be more effective in the high-risk vitamin D deficient group or not.

\section{Additional Information}

\section{Disclosures}

Conflicts of interest: In compliance with the ICMJE uniform disclosure form, all authors declare the following: Payment/services info: All authors have declared that no financial support was received from any organization for the submitted work. Financial relationships: All authors have declared that they have no financial relationships at present or within the previous three years with any organizations that might have an interest in the submitted work. Other relationships: All authors have declared that there are no other relationships or activities that could appear to have influenced the submitted work.

\section{References}

1. Moore WC, Meyers DA, Wenzel SE, et al.: Identification of asthma phenotypes using cluster analysis in the Severe Asthma Research Program. Am J Respir Crit Care Med. 2010, 181:315323. 10.1164/rccm.200906-08960C

2. Boulet L-P, FitzGerald JM, Levy ML, et al.: Asthma guidelines implementation: a guide to the translation of GINA guidelines into improved care. Eur Respir J. 2012, 39:1220-1229. 10.1183/09031936.00184511

3. Holt PG, Strickland DH: Interactions between innate and adaptive immunity in asthma pathogenesis: new perspectives from studies on acute exacerbations. J Allergy Clin Immunol. 2010, 125:963-972. 10.1016/j.jaci.2010.02.011

4. Bradding P, Walls AF, Holgate ST: The role of the mast cell in the pathophysiology of asthma . J Allergy Clin Immunol. 2006, 117:1277-1284. 10.1016/j.jaci.2006.02.039

5. Shifren A, Witt C, Christie C, et al.: Mechanisms of remodeling in asthmatic airways . J Allergy. 2012, 2012:12. 10.1155/2012/316049

6. Allan K, Devereux G: Diet and asthma: nutrition implications from prevention to treatment . J Am Diet Assoc. 2011, 111:258-268. 10.1016/j.jada.2010.10.048

7. Herr C, Greulich T, Koczulla RA, et al.: The role of vitamin D in pulmonary disease: COPD, asthma, infection, and cancer. Respir Res. 2011, 12:31. 10.1186/1465-9921-12-31

8. Nurmatov U, Devereux G, Sheikh A: Nutrients and foods for the primary prevention of asthma and allergy: systematic review and meta-analysis. J Allergy Clin Immunol. 2011, 127:724-733. 10.1016/j.jaci.2010.11.001

9. Mak G, Hanania NA: Vitamin D and asthma. Curr Opin Pulm Med. 2011, 17:1-5. 10.1097/MCP.0b013e3283411440

10. Chambers ES, Hawrylowicz CM: The impact of vitamin D on regulatory T cells . Curr Allergy Asthma Rep. 2011, 11:29-36. 10.1007/s11882-010-0161-8

11. Chishimba L, Thickett DR, Stockley RA, et al.: The vitamin D axis in the lung: a key role for vitamin D-binding protein. Thorax. 2010, 65:456-462. 10.1136/thx.2009.128793

12. Burke H, Leonardi-Bee J, Hashim A, et al.: Prenatal and passive smoke exposure and incidence of asthma and wheeze: systematic review and meta-analysis. Pediatrics. 2012, 129:735-744. 10.1542/peds.2011-2196

13. Bose S, Breysse PN, McCormack MC, et al.: Outdoor exposure and vitamin D levels in urban 
children with asthma. Nutr J. 2013, 12:81-87. 10.1186/1475-2891-12-81

14. Haines A, Davies E, Higgins B, et al.: Identifying the most cost-effective way of diagnosing asthma in adults using multiple tests-A cost-utility analysis from the Nice Asthma Guideline. Value Health. 2015, 18:A361. 10.1016/j.jval.2015.09.698

15. Smallwood J, Ownby D: Exposure to dog allergens and subsequent allergic sensitization: an updated review. Curr Allergy Asthma Rep. 2012, 12:424-428. 10.1007/s11882-012-0277-0

16. Collins SA, Pike KC, Inskip HM, et al.: Validation of novel wheeze phenotypes using longitudinal airway function and atopic sensitization data in the first 6 years of life: evidence from the Southampton Women's survey. Pediatr Pulmonol. 2013, 48:683-692. 10.1002/ppul.22766

17. Parodi V, de Florentiis D, Martini M, et al.: Inactivated influenza vaccines. Drugs Aging. 2011, 28:93-106. 10.2165/11586770-000000000-00000

18. Heaney RP, Holick MF: Why the IOM recommendations for vitamin D are deficient . J Bone Miner Res. 2011, 26:455-457. 10.1002/jbmr.328

19. Hughes AM, Lucas RM, Ponsonby AL, et al.: The role of latitude, ultraviolet radiation exposure and vitamin D in childhood asthma and hayfever: an Australian multicenter study. Pediatr Allergy Immunol. 2011, 22:327-333. 10.1111/j.1399-3038.2010.01099.x

20. Brehm JM, Celedn JC, Soto-Quiros ME, et al.: Serum vitamin D levels and markers of severity of childhood asthma in Costa Rica. Am J Respir Crit Care Med. 2009, 179:765-771.

10.1164/rccm.200808-13610C

21. Kumar J, Muntner P, Kaskel FJ, et al.: Prevalence and associations of 25-hydroxyvitamin D deficiency in US children: NHANES 2001-2004. Pediatrics. 2009, 124:362-370.

10.1542/peds.2009-0051

22. Campagna AM, Settgast AM, Walker PF, et al.: Effect of country of origin, age, and body mass index on prevalence of vitamin D deficiency in a US immigrant and refugee population. Mayo Clin Proc. 2013, 88:31-37. 10.1016/j.mayocp.2012.07.027

23. Mithal A, Wahl DA, Bonjour JP, et al.: Global vitamin D status and determinants of hypovitaminosis D. Osteoporos Int. 2009, 20:1807-1820. 10.1007/s00198-009-0954-6

24. Palacios C, Gonzalez L: Vitamin D deficiency: is vitamin D deficiency a major global public health problem. J Steroid Biochem Mol Biol. 2014, 144:138-145. 10.1016/j.jsbmb.2013.11.003

25. Brehm JM, Schuemann B, Fuhlbrigge AL, et al.: Serum vitamin D levels and severe asthma exacerbations in the Childhood Asthma Management Program study. J Allergy Clin Immunol. 2010, 126:52-58. 10.1016/j.jaci.2010.03.043

26. Carlberg C, Seuter S, Heikkinen S: The first genome-wide view of vitamin D receptor locations and their mechanistic implications. Anticancer Res. 2012, 32:271-282.

27. Baeke F, Takiishi T, Korf H, et al.: Vitamin D: modulator of the immune system. Curr Opin Pharmacol. 2010, 10:482-496. 10.1016/j.coph.2010.04.001

28. Chinellato I, Piazza M, Sandri M, et al.: Vitamin D serum levels and markers of asthma control in Italian children. J Pediatr. 2011, 158:437-441. 10.1016/j.jpeds.2010.08.043

29. Devereux G, Wilson A, Avenell A, et al.: A case-control study of vitamin D status and asthma in adults. Allergy. 2014, 65:666-667. 10.1111/j.1398-9995.2009.02220.x

30. Urashima M, Segawa T, Okazaki M, et al.: Randomized trial of vitamin D supplementation to prevent seasonal influenza A in schoolchildren. Am J Clin Nutr. 2010, 91:1255-1260. 10.3945/ajcn.2009.29094

31. Majak P, Olszowiec-Chlebna Mg, Smejda K, et al.: Vitamin D supplementation in children may prevent asthma exacerbation triggered by acute respiratory infection. J Allergy Clin Immunol. 2011, 127:1294-1296. 10.1016/j.jaci.2010.12.016

32. Yadav M, Mittal K: Effect of vitamin D supplementation on moderate to severe bronchial asthma. Indian J Pediatr. 2014, 81:650-654. 10.1007/s12098-013-1268-4

33. Gale CR, Robinson SM, Harvey NC, et al.: Maternal vitamin D status during pregnancy and child outcomes. Eur J Clin Nutr. 2008, 62:68-77. 10.1038/sj.ejcn.1602680

34. Hollams EM, Hart PH, Holt BJ, et al.: Vitamin D and atopy and asthma phenotypes in children: a longitudinal cohort study. Eur Respir J. 2011, 38:1320-1327. 10.1183/09031936.00029011

35. Thuesen BH, Skaaby T, Husemoen LLN, et al.: The association of serum $25 \mathrm{OH}$ vitamin D with atopy, asthma, and lung function in a prospective study of Danish adults. Clin Exp Allergy. 2015, 45:265-272. 10.1111/cea.12299

36. Freishtat RJ, Iqbal SF, Pillai DK, et al.: High prevalence of vitamin D deficiency among innercity African American youth with asthma in Washington, DC. J Pediatr. 2010, 156:948-952. 
10.1016/j.jpeds.2009.12.033

37. Brehm JM, Acosta-Perez E, Klei L, et al.: Vitamin D insufficiency and severe asthma exacerbations in Puerto Rican children. Am J Respir Crit Care Med. 2012, 186:140-146. 10.1164/rccm.201203-04310C

38. Montero-Arias F, Sed-Meja G, Ramos-Esquivel A: Vitamin D insufficiency and asthma severity in adults from Costa Rica. Allergy Asthma Immunol Res. 2013, 5:283-288.

10.4168/aair.2013.5.5.283

39. Miyake Y, Sasaki S, Tanaka K, et al.: Dairy food, calcium and vitamin D intake in pregnancy, and wheeze and eczema in infants. Eur Respir J. 2010, 35:1228-1234. 10.1183/09031936.00100609

40. Zosky GR, Hart PH, Whitehouse AJO, et al.: Vitamin D deficiency at 16-20 weeks gestation is associated with impaired lung function and asthma at 6 years of age. Ann Am Thorac Soc. 2014, 11:571-577. 10.1513/AnnalsATS.201312-4230C

41. Devereux G, Litonjua AA, Turner SW, et al.: Maternal vitamin D intake during pregnancy and early childhood wheezing. Am J Clin Nutr. 2007, 85:853-859.

42. Erkkola M, Kaila M, Nwaru BI, et al.: Maternal vitamin D intake during pregnancy is inversely associated with asthma and allergic rhinitis in 5-year-old children. Clin Exp Allergy. 2009, 39:875-882. 10.1111/j.1365-2222.2009.03234.x

43. Morales E, Romieu I, Guerra S, et al.: Maternal vitamin D status in pregnancy and risk of lower respiratory tract infections, wheezing, and asthma in offspring. Epidemiology. 2012, 23:6471. 10.1097/EDE.0b013e31823a44d3

44. Camargo CA, Ingham T, Wickens K, et al.: Cord-blood 25-hydroxyvitamin D levels and risk of respiratory infection, wheezing, and asthma. Pediatrics. 2011, 127:180-187.

10.1542/peds.2010-0442

45. Gupta A, Dimeloe S, Richards DF, et al.: Defective IL-10 expression and in vitro steroidinduced IL-17A in paediatric severe therapy-resistant asthma. Thorax. 2014, 69:508-515. 10.1136/thoraxjnl-2013-203421

46. Shahin MYA, El-lawah AA, Amin A, et al.: Study of serum vitamin D level in adult patients with bronchial asthma. Egypt J Chest Dis Tuberc. 2017, 66:5-9. 10.1016/j.ejcdt.2016.11.005

47. Tachimoto H, Mezawa H, Segawa T, et al.: Improved control of childhood asthma with low dose, short term vitamin D supplementation: a randomized, double-blind, placebo-controlled trial. Allergy. 2016, 71:1001-1009. 10.1111/all.12856

48. Jensen ME, Mailhot G, Alos N, et al.: Vitamin D intervention in preschoolers with viralinduced asthma (DIVA): a pilot randomised controlled trial. Trials. 2016, 17:353-361. 10.1186/s13063-016-1483-1

49. Denlinger LC, King TS, Cardet JC, et al.: Vitamin D supplementation and the risk of colds in patients with asthma. Am J Respir Crit Care Med. 2016, 193:634-641. 10.1164/rccm.20150611690C

50. Martineau AR, MacLaughlin BD, Hooper RL, et al.: Double-blind randomised placebocontrolled trial of bolus-dose vitamin D3 supplementation in adults with asthma (ViDiAs). Thorax. 2015, 70:451-457. 10.1136/thoraxjnl-2014-206449 